\title{
OXA-48-Carbapenemase-Producing Klebsiella pneumoniae infections - the first cases diagnosed in Romanian National Institute of Infectious Diseases
}

\section{Infecții cu Klebsiella pneumoniae producătoare de carbapenemază OXA-48 - primele cazuri diagnosticate într-un institut românesc de boli infecțioase}

\author{
Cristina Popescu ${ }^{1,2}$, Gabriel Adrian Popescu ${ }^{1,2 *}$, Olga Dorobăț ${ }^{2}$, \\ Alexandru Rafilă ${ }^{1,2}$, Diana Tănase ${ }^{2}$, Claudia Mikula ${ }^{3,4}$, \\ Gudrun Weissensteiner ${ }^{3,4}$, Steliana Huhulescu ${ }^{3,5}$ \\ ', Carol Davila" University of Medicine and Pharmacy, Bucharest, Romania \\ 2,,Matei Balș, National Institute for Infectious Diseases, Bucharest, Romania, \\ ${ }^{3}$ Austrian Agency for Health and Food Safety, Vienna, Austria, \\ ${ }^{4}$ Institute for Medical Microbiology and Hygiene, Graz, Austria, \\ ${ }^{5}$ Institute for Medical Microbiology and Hygiene, Vienna, Austria
}

\begin{abstract}
We report first description of clinical cases of OXA-48 carbapenemase-producing Klebsiella pneumoniae originating from patients hospitalized in the most important Infectious Diseases Hospital from Romania, between December 2012 and March 2013. All strains were isolated from patients who were previously admitted in surgical wards. None of the patients had been admitted in a hospital outside of Romania.
\end{abstract}

Keywords: Klebsiella pneumoniae; OXA-48 carbapenemase;ESBL; risk factors for resistance.

\section{Rezumat}

Prezentăm patru pacienți internați în Institutul Național de Boli Infecțioase „,Matei Balș” de la care s-a izolat Klebsiella pneumoniae producătoare de carbapenemază OXA-48. Izolările bacteriene s-au efectuat în perioada decembrie 2012-martie 2013. Niciunul dintre pacienți nu fusese spitalizat în afara României, în schimb toți fuseseră anterior spitalizați în diverse secții cu profil chirurgical.

Cuvinte cheie: Klebsiella pneumoniae; carbapenemaza OXA-48; ESBL; factori de risc pentru rezistență la antibiotice.

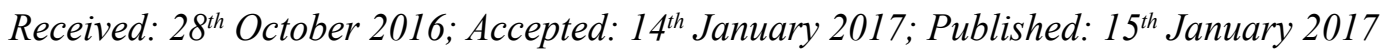

* Corresponding author: Gabriel Adrian Popescu, Matei Balș National Institute of Infectious Diseases, Bucharest, Romania, e-mail: gabrielp9@yahoo.com 


\section{Background}

The development of resistance to carbapenems as the last available therapy line of antimicrobials represents a special concern issue in infectious diseases. Carbapenemases - producing Enterobacteriaceae (CPE) are sometimes difficult to detect even with the new breakpoints of EUCAST and CLSI. It is important to confirm the presence of carbapenemase genes by PCR techniques in order to implement interventions which can avoid potential serious hospital epidemics. There are 3 classes of carbapenemases: class A (KP carbapenemases - KPC), class $\mathrm{B}$ (metallo-betalactamases - MBLs) and class D oxacillinases (among them OXA-48-like enzymes) (1). The presence of OXA-48-like producing CPE was initially reported as endemic in Turkey, Northern Africa and Middle East (2-5) but more recently several other countries signaled sporadic cases and/or epidemic evolution in several surveillance studies, especially in the USA, India and some European countries (6-10).

In October 2011 ECDC initiated a communication of risk assessment for CPE importation in Europe related to Libyan patients transferred to European hospitals (11). Slovenian colleagues communicated in December 2011 the first case of OXA-48 K pneumoniae colonization in a hospitalized patient (12). In 2012 several Libyan patients were transferred to Bucharest hospitals; being concerned of the difficulty to identify carbapenem resistant Enterobacteriaceae (CRE) testing for antimicrobial susceptibility with panels adapted from the older clinical breakpoints of CLSI, we initiated a cooperative study with AGES (Austrian Agency for Public Health and Food Safety). The work included the characterization of $K$. pneumoniae isolates. Among all strains of $K$. pneumoniae isolated in our hospital during the four months period (December 2012- March 2013), we identified by testing with semi-automated methods (MicroScan or Vitek) a number of 18 strains having $3^{\text {rd }}$ generation cephalosporin resistance and a positive modified Hodge test. In accordance with CLSI 2010 breakpoints (still in use in our hospital in the first months of 2013), these testing panels indicated imipenem susceptibility as CMI $\leq 4 \mathrm{mg} / \mathrm{L}$. The isolates were sent to AGES in order to perform the detection of ESBL and carbapenemases production. Multiplex-PCR amplifications were carried out for the detection of genes encoding the extended spectrum betalactamases, including TEM, SHV, OXA (multiplex assay), CTX-M-1, -2, -9 (multiplex assay), OXA-48 carbapenemase (singleplex assay) and carbapenemase genes VIM and KPC (multiplex assay) with primers previously described (13). Plasmid-mediated AmpC $\beta$-lactamase gene clusters FOX, ACC, CIT, DHA, MOX, EBC were detected in a multiplex assay $(\mathrm{AmpC})$ using primers previously described (14).

All isolates exhibit several beta-lactamases production and four isolates were OXA-48 positive. No KPC-producing isolates were retrieved. (Table 1).

We studied the clinical history of these four patients in order to describe the common findings and to identify patients with increased risk of OXA-48-producing K.pneumoniae infection or colonization (Table 2).

\section{The first case}

In December 2012 a 76 year-old woman was admitted in "Matei Bals" National Institute of Infectious Diseases (MB-NIID) for the treatment of a post-surgery infection presumed to be produced by methicillin resistant Staphylococcus aureus (MRSA). The patient had been diagnosed with recto-sigmoid adenocarcinoma in august 2012 with a single liver metastasis. After two weeks, a Hartman's procedure and also liver metastasis resection were performed. After another two weeks, an intraabdominal collection 
Table 1. The associated ESBL's genes in OXA-48carbapenemase-producing $\mathrm{K}$ pneumoniae isolates

\begin{tabular}{lccc}
\hline Patient & ESBL-Gene(s) & ampC-Gene & Carbapenemase \\
\hline 1 & TEM, SHV, CTX-M-1 & Negative & OXA-48 \\
\hline 2 & TEM, SHV, OXA, CTX-M-1 & Negative & OXA-48 \\
\hline 3 & SHV, CTX-M-1 & Negative & OXA-48 \\
\hline 4 & SHV, CTX-M-1 & Negative & OXA-48 \\
\hline
\end{tabular}

All strains were negative for KPC and VIM

Table 2. The cases synopsis

\begin{tabular}{lllll}
\hline Findings & Case 1 & Case 2 & Case 3 & Case 4 \\
\hline Age (year-old) & 76 & 92 & 85 & 67 \\
\hline Gender & Female & Female & Male & Female \\
\hline $\begin{array}{l}\text { Previous hospital- } \\
\text { ization }\end{array}$ & $\begin{array}{l}\text { Yes } \\
\text { (surgery ward) }\end{array}$ & $\begin{array}{l}\text { Yes } \\
\text { (urology ward) }\end{array}$ & $\begin{array}{l}\text { Yes (surgery and } \\
\text { cardiology wards) }\end{array}$ & $\begin{array}{l}\text { Yes } \\
\text { (surgery ward) }\end{array}$ \\
\hline $\begin{array}{l}\text { Site of KP isola- } \\
\text { tion }\end{array}$ & Wound & Urine & $\begin{array}{l}\text { Blood } \\
\text { Urine }\end{array}$ & Blood \\
$\begin{array}{l}\text { Infection vs colo- } \\
\text { nization }\end{array}$ & $\begin{array}{l}\text { Surgical site infec- } \\
\text { tion }\end{array}$ & $\begin{array}{l}\text { Colonization } \\
\text { (asymptomatic } \\
\text { bacteriuria) }\end{array}$ & $\begin{array}{l}\text { Infection (bacter- } \\
\text { emia) }\end{array}$ & $\begin{array}{l}\text { Infection (bacte- } \\
\text { remia) }\end{array}$ \\
$\begin{array}{l}\text { Antimicrobial } \\
\text { therapy }\end{array}$ & Imipenem & No therapy for KP & $\begin{array}{l}\text { Colistin and TMP/ } \\
\text { SMX }\end{array}$ & TMP/SMX \\
\hline \begin{tabular}{l} 
Outcome \\
\hline
\end{tabular} & Favorable & Favorable & Favorable & Deceased \\
\hline
\end{tabular}

was found and a second surgical intervention was performed. Because a persistent purulent secretion was observed from the surgical wound she was admitted in our hospital. At the admission, the patient was afebrile, without systemic inflammatory response syndrome (SIRS), with normal vital signs, without pulmonary, cardiac or intraabdominal signs of infection and with a purulent secretion from the surgical wound. A strain of MRSA from the purulent secretion was isolated in the department of surgery at Fundeni Hospital and the patient received anti-MRSA therapy with the persistence of symptoms. In our hospital, two germs were isolated from wound: a MRSA strain and also a K.pneumoniae strain with extended spectrum betalactamases (ESBL), resistant to ertapenem, penicillin plus betalactamases inhibitors (BLI), cephalosporins, fluoroquinolones, trimethoprim/sulfamethoxazole (TMP/SMX) and aminoglycosides. The strain was characterized as susceptible to imipenem, meropenem and colistin. The patient received therapy with imipenem and vancomycin for 14 days with slow favorable outcome and wound healing.

\section{The second case}

In December 2012 a 92 year-old woman was admitted in MB-NIID for the treatment of a post-antibiotic Clostridium difficile diarrhea. The patient had been diagnosed with left ure- 
teral neoplasia in November 2012 and a left nephro-ureterectomy was performed. After surgery, she received antimicrobial therapy with cefoperazone-sulbactam and ciprofloxacin in the urology department and two weeks later she developed severe diarrhea with dehydration and fever. The PCR for Clostridium difficile performed from stool in the infectious diseases department was positive. At the same time, a strain of $\mathrm{K}$. pneumoniae ESBL-producing from urine-culture, without symptoms (asymptomatic bacteriuria) was isolated in our hospital. The strain was resistant to: penicillin-BLI, cephalosporins, ertapenem, fluoroquinolones and aminoglycosides and it was characterized as susceptible to imipenem and colistin. The patient received oral metronidazole for 10 days with a good outcome of the diarrhea. She did not receive antimicrobial therapy for this episode of asymptomatic bacteriuria.

\section{The third case}

In February 2013, an 85 year-old male, known with type 2 diabetes mellitus treated with insulin, chronic kidney disease, cardiac insufficiency and chronic anemia was admitted in our hospital for fever, chills, disorientation, dyspnea and tachypnea. The patient had received medical services repeatedly in the past six months (including in a surgery ward) and urinary catheterization was performed during the previous hospitalization. In December 2012, during a coronary ICU hospitalization, he developed two episodes of urinary tract infection: the first with $K$. pneumoniae without ESBL (treated with ceftriaxone) and the second one with Pseudomonas aeruginosa resistant to carbapenems (treated with levofloxacin and colistin).

At the admission in our hospital the patient had SIRS: fever, tachycardia, tachypnea and leukocytosis, normal arterial blood pressure, without evidence of organ insufficiency, with symptoms of urinary tract infection: dysuria, polakiuria and hypogastric pain. The antimicrobial therapy was empirically initiated with ceftriaxone and levofloxacin. After 48 hours, a strain of $\mathrm{K}$. pneumoniae ESBL-producing was isolated from blood-culture and urine-culture, susceptible to colistin, imipenem and TMP/SMX and resistant to third generation cephalosporins, ertapenem and penicillin-BLI's. The antimicrobial therapy switched to colistin and TMP/SMX with dosage adapted to creatinine clearance for 12 days with good outcome. The patient was discharged after 15 days.

\section{The fourth case}

In March 2013, a 67 year-old female who underwent a hemicolectomy for cecum carcinoma, developed fever, chills, tachycardia and tachypnea during the ICU postoperative period. A blood-culture was performed and an ESBL-producing strain of $K$. pneumoniae was isolated. This strain was resistant to: carbapenems (both ertapenem and imipenem), penicillin -BLI, cephalosporins, fluoroquinolones, aminoglycosides and colistin. The strain was sensitive only to TMP/SMX. The patient received TMP/SMX with unfavorable outcome and died after 5 days.

\section{Discussion}

Organism identification and susceptibility testing were performed for all the strains using semiautomatic methods (VITEK 2,-BioMerieux, Mercy L'Etoile, France and MicroScan, West Sacramento, CA, USA). The interpretation of results was made according to CLSI 2010 rules. E-tests were used for colistin. (Table 3).

Class D betalactamases, named oxacillinases (OXA), were initially associated with Acinetobacter baumannii strains. Although at the beginning Enterobacteriaceae strains were not associated with this type of carbapenemases, OXA-48 
Table 3. Antimicrobial susceptibility tests for the four OXA-48 producing isolates

\begin{tabular}{lllllllll}
\hline Antimicrobials & Case 1 & \multicolumn{3}{c}{ Case 2 } & \multicolumn{2}{c}{ Case 3 } & \multicolumn{2}{c}{ Case 4 } \\
\hline & $\begin{array}{l}\text { CMI } \\
(\mathbf{m c g} / \mathbf{m I})\end{array}$ & $\begin{array}{l}\text { Interpre- } \\
\text { tation } \mathbf{( I )}\end{array}$ & & & & & & \\
& $>16$ & $\mathrm{R}$ & $>16$ & $\mathrm{R}$ & $>16$ & $\mathrm{R}$ & $>32$ & $\mathrm{R}$ \\
\hline Ampicillin-sulbactam & $>16$ & $\mathrm{R}$ & $>16$ & $\mathrm{R}$ & $>16$ & $\mathrm{R}$ & $>32$ & $\mathrm{R}$ \\
\hline Amoxicillin- clavulanic acid & $>64$ & $\mathrm{R}$ & $>64$ & $\mathrm{R}$ & $>16$ & $\mathrm{R}$ & $>128$ & $\mathrm{R}$ \\
\hline Piperacillin tazobactam & 8 & $\mathrm{R}$ & $>16$ & $\mathrm{R}$ & $>16$ & $\mathrm{R}$ & $>64$ & $\mathrm{R}$ \\
\hline Ceftazidime & $>32$ & $\mathrm{R}$ & $>32$ & $\mathrm{R}$ & $>32$ & $\mathrm{R}$ & $>64$ & $\mathrm{R}$ \\
\hline Cefotaxime & $>16$ & $\mathrm{R}$ & $>16$ & $\mathrm{R}$ & $>16$ & $\mathrm{R}$ & $>64$ & $\mathrm{R}$ \\
\hline Cefepime & $<8$ & $\mathrm{~S}$ & - & & - & - & - & - \\
\hline Cefoxitin & $>4$ & $\mathrm{R}$ & $>4$ & $\mathrm{R}$ & $>4$ & $\mathrm{R}$ & $>4$ & $\mathrm{R}$ \\
\hline Ertapenem & $<4$ & $\mathrm{~S}$ & $<4$ & $\mathrm{~S}$ & $<4$ & $\mathrm{~S}$ & $>8$ & $\mathrm{R}$ \\
\hline Imipenem & $<4$ & $\mathrm{~S}$ & - & - & - & - & - & - \\
\hline Meropenem & $<16$ & $\mathrm{~S}$ & 32 & $\mathrm{R}$ & $<8$ & $\mathrm{~S}$ & $<2$ & $\mathrm{~S}$ \\
\hline Amikacin & $>8$ & $\mathrm{R}$ & $>8$ & $\mathrm{R}$ & $>8$ & $\mathrm{R}$ & - & - \\
\hline Tobramycin & $>2$ & $\mathrm{R}$ & $>2$ & $\mathrm{R}$ & $>2$ & $\mathrm{R}$ & $>4$ & $\mathrm{R}$ \\
\hline Ciprofloxacin & $>4$ & $\mathrm{R}$ & $>4$ & $\mathrm{R}$ & $>4$ & $\mathrm{R}$ & - & - \\
\hline Levofloxacin & $>8$ & $\mathrm{R}$ & 8 & $\mathrm{R}$ & $>8$ & $\mathrm{R}$ & 8 & $\mathrm{R}$ \\
\hline Tetracycline & $>2$ & $\mathrm{R}$ & $>2$ & $\mathrm{R}$ & $<2$ & $\mathrm{~S}$ & $<2$ & $\mathrm{~S}$ \\
\hline Trimethoprim sulfamethox- & & & & & & & & \\
azole & .38 & $\mathrm{~S}$ & .5 & $\mathrm{~S}$ & 2 & $\mathrm{~S}$ & 4 & $\mathrm{R}$ \\
\hline Colistin (E-test) & & & & & & &
\end{tabular}

and related variants emerged in Enterobacteriaceae. OXA-48 producing $K$. pneumoniae is difficult to detect because these strains weakly hydrolyze carbapenems, some broad-spectrum cephalosporins, such as ceftazidime and cefepime, and aztreonam. (2) All the described strains were resistant to third and fourth generation cephalosporins, probably due to associated production of oxacillinases and ESBL. The MIC value for carbapenems is also higher in OXA-48 producers when an ESBL production is associated. (15)

Several articles published in the last years signaled the presence of OXA-48 K. pneumoni$a e$ isolates starting with 2010 in patients admitted in hospitals from different cities in Romania (16-19). We described the first cases of OXA-48
K. pneumoniae infections diagnosed in our hospital. All cases were admitted in surgical wards and underwent some surgical procedure. In three cases, broad spectrum antimicrobial therapy was necessary. None of the patients had any history of carbapenem exposure prior to the detection of OXA-48 KP.

The Hodge modified test could be useful to detect OXA-48 KP producers. The rectal screening of all patients for CRE could be negative even in patients colonized with such-a bacteria. However, rectal screening for CRE must continue in all areas where this CPE emergence was described.

The data presented in this article had some limitations. First of all this is a case series presentation and we did not perform a study with 
a well-established design. We started with the identification of OXA-48 K. pneumoniae strains and then we analyzed the patients. Another limitation was the absence of molecular epidemiology analysis of cases filiation.

In conclusion, the emergence of CRE in Romania after 2010, highlighted the importance of antimicrobial resistance surveillance especially in countries with limited resources. The molecular characterization can ensure an early recognition of CRE. It seems reasonable that first CRE strains including OXA-48 K. pneumoniae were imported before 2010 in Romania from endemic areas: United States, Greece and Israel for KPCs, Turkey for OXA-48 K. pneumoniae, India for NDMs and Greece for VIMs. $(15,20)$. However, our case reports suggest that in 20122013 already existed a risk for the patients to be colonized with such strains in Romanian hospitals. It is therefore important to improve both infection control practice and antimicrobial stewardship in order to limit CRE spread in Romania.

\section{References}

1. Poirel L, Pitout JD, Nordmann P. Carbapenemases: molecular diversity and clinical consequences. Future Microbiol. 2007 Oct;2(5): 501-12. DOI: $10.2217 / 17460913.2 .5 .501$

2. Poirel L, Héritier C, Tolün V, Nordmann P. Emergence of oxacillinase-mediated resistance to imipenem in Klebsiella pneumoniae. Antimicrob Agents Chemother. 2004 Jan;48(1):15-22. DOI: 10.1128/AAC.48.1.1522.2004

3. Carrër A, Poirel L, Yilmaz M, Akan OA, Feriha C, Cuzon G, et al. Spread of OXA-48-encoding plasmid in Turkey and beyond. Antimicrob Agents Chemother. 2010 Mar;54(3):1369-73. DOI: 10.1128/AAC.01312-09

4. Benouda A, Touzani O, Khairallah MT, Araj GF, Matar GM. First detection of oxacillinase-mediated resistance to carbapenems in Klebsiella pneumoniae from Morocco. Ann Trop Med Parasitol. 2010 Jun;104(4):327-30. DOI: 10.1179/136485910X12743 554760108
5. Poirel L, Potron A, Nordmann P. OXA-48-like carbapenemases: the phantom menace. J Antimicrob Chemother. 2012 Jul;67(7):1597-606. DOI: 10.1093/ $\mathrm{jac} / \mathrm{dks} 121$

6. Lascols C, Peirano G, Hackel M Laupland KB, Pitout JD. Surveillance and molecular epidemiology of Klebsiella pneumoniae isolates that produce carbapenemases: first report of OXA-48-like enzymes in North America. Antimicrob Agents Chemother. 2013 Jan;57(1):130-6. DOI: 10.1128/AAC.01686-12

7. Lascols C, Hackel M, Marshal SH, Hujer AM, Bouchillon S, Badal R, et al. Increasing prevalence and dissemination of NDM-1 metallo-betalactamases in India: data from the SMART study. J Antimicrob Chemother. 2009 Sep;66(9):1992-7. DOI: 10.1093/jac/ dkr240

8. Vaux S, Carbonne A, Thiolet JM, Jarlier V, Coignard B. Emergence of carbapenemase-producing enterobacteriaceae in France, 2004 to 2011. Euro Surveill. 2011 Jun;16(22):pii=19880.

9. Osterblad M, Kirveskari J, Hakanen AJ, Tissari P, Vaara M, Jalava J. Carbapenemase-producing Enterobacteriaceae in Finland: the first years (200811). J Antimicrob Chemother. 2012 Dec;67(12):28604. DOI: $10.1093 / \mathrm{jac} / \mathrm{dks} 299$

10. O’Brien DJ, Wrenn C, Roche C Rose L, Fenelon C, Flynn A, et al. First isolation and outbreak of OXA48-producing Klebsiella pneumoniae in an Irish hospital, March to June 2011. Euro Surveillance. 2011 Jul;16(29):pii=19921.

11. European Centre for Disease Prevention and Control (ECDC). Rapid risk assessment. Transfer of Libyan patients to hospitals in the European Union. Stockholm: ECDC; 31 Oct 2011.

12. Pirš M, Andlovic A, Cerar T, Žohar-Čretnik T, Kobola L, Kolman J, et al. A case of OXA-48 carbapenemase-producing Klebsiella pneumoniae in a patient transferred to Slovenia from Libya, November 2011. Euro Surveill. 2011 Dec;16(50):pii=20042. 
13. Dallenne C, Da Costa A, Decré D, Favier C, Arlet G. Development of a set of multiplex PCR assays for the detection of genes encoding important beta-lactamases in Enterobacteriaceae. J Antimicrob Chemother. 2010 Mar; 65(3):490-5. DOI: 10.1093/jac/dkp498

14. Perez-Perez FJ, Hanson ND. Detection of plasmid-mediated AmpC $\beta$-lactamase genes in clinical isolates by using multiplex PCR. J Clin Microbiol. 2002 Jun;40(6):2153-62. DOI: 10.1128/JCM.40.6.21532162.2002

15. Nordmann P, Naas T, Poirel L. Global spread of carbapenemase-producing enterobacteriaceae. Emerg Infect Dis. 2011 Oct;17(10):1791-8. DOI: 10.3201/ eid1710.110655

16. Szekely E, Damjanova I, Janvari L, Vas K.E, Molnar S, Bilca DV, et al. First description of blaNDM-1, blaOXA-48, blaOXA-181 producing Enterobacteriaceae strains in Romania. Int $\mathrm{J}$ Med Microbiol.2013 Dec; 303(8): 697-700. DOI: 10.1016/j. ijmm.2013.10.001

17. Dortet L, Flonta M, Boudehen Y-M, Creton E, Bernabeu $\mathrm{S}$, Vogel A, et al. Dissemination of carbapenemase-producing Enterobacteriaceae and Pseudomonas aeruginosa in Romania. Antimicrob Agents Chemother . 2015 Nov; 59(11) 7100-3. DOI: 10.1128/AAC.01512-15

18. Gheorghe I, Czobor I, Chifiriuc MC, Borcan E, Ghita $\mathrm{C}$, Banu $\mathrm{O}$ et al. Molecular screening of carbapenemase- producing Gram-negative strains in Romanian intensive care units during a one year survey. J Med Microbiol. 2014 Oct; 63 (Pt 10):1303-10. DOI: 10.1099/jmm.0.074039-0

19. Timofte D, Panzaru CV, Maciuca IE, Dan M, Mare $\mathrm{AD}, \mathrm{Man} \mathrm{A}$, et al. Active surveillance scheme in three Romanian hospitals reveals a high prevalence and variety of carbapenamase-producing Gram-negative bacteria: a pilot study, December 2014 to May 2015. Euro Surveill. 2016 Jun 23; 21(25): pii=30262. DOI: 10.2807/1560-7917.ES.2016.21.25.30262

20. Van der Bij AK, Pitout JD. The role of international travel in the worldwide spread of multiresistant Enterobacteriaceae. J Antimicrob Chemother. 2012 Sep;67(9):2090-100. DOI: 10.1093/jac/dks214 